\title{
Sphenomandibular Muscle or Deep Bundle of Temporal Muscle?
}

\author{
¿Músculo Esfenomandibular o Fascículo Profundo del Músculo Temporal? \\ Evanisi Teresa Palomari*; Luís Ronaldo Picosse**; Mayta P. Tobo***; \\ Ricardo Noboro Isayama ${ }^{* * * * *} \&$ Marcelo Rodrigues da Cunha ${ }^{* * * * * *}$
}

PAlOMARI, E. T.; PICOSSE, L. R.; TOBO, M. P.; ISAYAMA, N. R. \& DA CUNHA, M. R. Sphenomandibular muscle or deep bundle of temporal muscle? Int. J. Morphol., 31(4):1158-1161, 2013.

SUMMARY: The muscle designated by a group of authors as the sphenomandibular or, according to recent studies, the deep bundle of the temporal muscle, presents important anatomical relationships, especially in a medical-odontological context. In view of this divergence, the aim of the present study was to observe the morphology by means of dissection of the formaldehyde-preserved heads, using two different techniques to access the muscle region in question, designated as trans-zygomatic and frontal access routes. The results permitted, by observation of the dissections frontally, the presence of fascicles standing apart from the deep bundle muscle venter, which was named intermediary bundle. This bundle presented two portions, a meaty upper portion and a tendinous lower portion, which continues with the tendinous part of the superficial bundle present on the internal surface of the coronoid process. In view of the material observations, it can be concluded that, due to the total absence of muscular fascia between its bundles, the temporal muscle is a unique entity presenting three bundles - the deep, the intermediate and the superficial.

KEY WORDS: Sphenomandibular muscle; Dissection; Deep bundle of the temporal muscle.

\section{INTRODUCTION}

Because of the divergences relative to the denominated muscle by Dunn et al. (1996) as sphenomandibular or as known since the beginning of the century by Poirier (1912), Ramalho et al. (1978), Türp, et al. (1997), Shimokawa et al. (1998), and Gaudy (2001), as being the deep bundle of the temporalis muscle, we saw the need to discover such an anatomical structure, by dissections, as an attempt to reduce the existent divergence in its respect.

Its presence, together with the medial portion of the temporalis muscle (Shon Ybarra \& Bauer, 2001) has caused a medical-odontological polemic, due to its association with facial pain and painful sensations in the posterior area of the eyes (Dunn et al.). On the other hand, concerning the odontological aspect, this muscle, besides presenting important anatomical relationships, has an important influence on the stability of removable, total or partial dental prostheses, inserted as it is in the external border of the retromolar trigone, as noticed during the dissections to be consistent with the above-mentioned authors.
The objective of this work was to approach a polemic theme and briefly report on existent data in the classic anatomical literature, thus supporting the position so that the same has continuity in a future, more detailed study.

\section{MATERIAL AND METHOD}

To analyze the sphenomandibular muscle, or the denominated deep bundle of the temporalis muscle, then formaldehyde-preserved heads were dissected, all between 35 and 55 years old and of the male sex. So that the access to the anatomical structure could be properly reached, conventional dissection techniques were used, with the aid, however, of a Coleman stereoscopic surgical microscope with zoom, model XTB-1B.

To accomplish the objective of this work, the procedures were restricted to two distinct accesses to the

\footnotetext{
* Department of Structural Biology and Functional, IB, Campinas State University, UNICAMP, Campinas, Brazil.

** Department of Anatomy, University of São Paulo, ICB/USP, São Paulo, Brazil.

*** Faculty of Dentistry, University of São Paulo, USP, São Paulo, Brazil

***** Adventist University Center of São Paulo, São Paulo, Brazil.

****** Department of Morphology and Pathology, Faculty of Medicine of Jundiaí, São Paulo, Brazil.
} 
area of the muscle in question, designated as trans-zygomatic and frontal access routes (Fig. 1).

In relation to the trans-zygomatic access, after the dissection of the superficial soft tissue and of the zygomatic bone, the infratemporal fossa was entered, by resection the coronoid process, as well as fibers of the superficial bundle of the temporalis muscle. After resection, the fibers of the deep bundle were found and separated with great difficulty, due to the absence of its own fascia between the two bunches (Fig.1).

By the frontal route, the anatomical pieces were partially reduced through a frontal cut at the height of the middle third of the orbital cavity and, with this, better visualization of both muscular bundles was achieved (Fig.1). Following reduction process of the pieces, the deep bundle of the temporalis muscle was highlighted with greater clarity, It was consequently verified that the frontal route was better suited to the objectives; this direction was then followed.

\section{RESULTS}

Singling out the prismatic triangle aspect of the deep bundle of the studied muscle, whose base or origin is in the external face of the larger wing of the sphenoid bone (in the infratemporal crest and tubercule) and whose apex or insertion point is in the temporal crest of the mandible and medial border of the retromolar trigone, it was noticed, in all the heads dissected by the frontal route, the presence of outstanding fascicles of the deep bundle muscle venter, which were denominated as the intermediate bundle. It was not possible to see the presence of these fascicles in the transzygomatic route dissections, given the great destruction of superimposed structures, thus losing important anatomical references intimately related to the bundle in question. This intermediate bundle presents a fleshy superior portion, and an inferior tendinous portion that continues with the likewise tendinous portion of the superficial bundle, in its descending itinerary along the temporalis crest, existent in the internal face of the coronoid process. Some fibers of this bundle seem to be inserted in the mandibular lingual (Fig. 1).

\section{DISCUSSION}

As the classic anatomy treaty of Shankland et al. (1996) accentuated, it could be observed that the deep or sphenoidal face descends to a distinct accessory fascicle, going to the mylo-hyoid line and that its superficial fibers

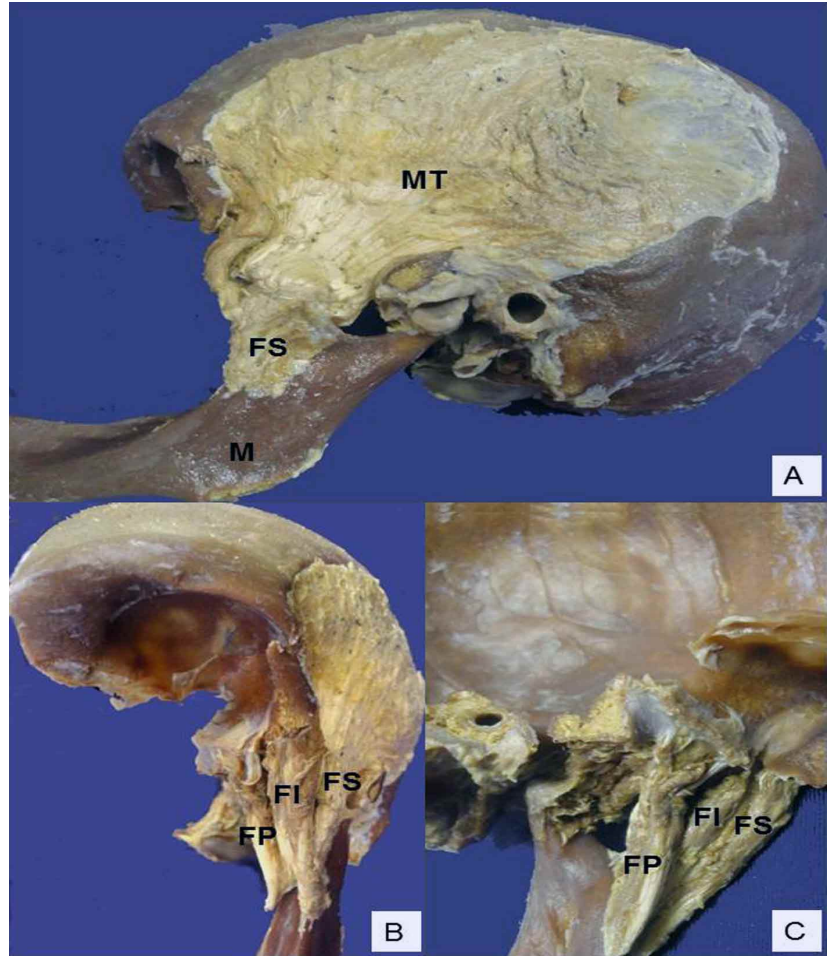

Fig 1. Temporal region of the skull in lateral view (A), anterior (B) and medial (C). In A, note the temporal muscle (MT) entering the branch of the mandible (M) as the beam surface (FS). In B and C note intermediate beams (FI) and deep (FP) the latter being characterized as muscle sphenomandibular.

continue as well with the fibers of the buccinator. According Sedlmayr et al. (2009), the beams deep temporal muscle is inserted into the temporal fossa and the coronoid process, interdigitating with the buccinator muscle. Ramalho et al., in their studies on the sphenoid tubercle could also observe the presence of the deep bundle of the temporalis muscle and that this presented three different faces, denominated by the authors as the anterior, posterior-medial and lateral.

Sicher \& Tandler (1981), refer to, in what concerns the insertion of the temporalis muscle, an origin zone that extends to the sphenoid-temporal or infratemporal crest; ahead and below, occupying the greater wing of the sphenoid and the posterior part of the temporalis face of the zygomatic bone.

The insertion of the muscle is made by two tendinous portions clearly separated from each other, a superficial tendinous portion that is inserted in the border of the coronoid process, and a deep tendon that is inserted in the medial face of the coronoid process, in a zone that extends from its apex to below the temporalis crest. Miller (1991) reported the existence of a deep bundle in the temporalis muscle 
originating in the infratemporal crest; on the other hand, however, Ernest et al. (1991), also described a deep bundle of the temporalis muscle and that this formed a medial venter in the temporalis tendon whose insertion was in the mandibular branch as well as in its base.

Geers et al. (2005), performed dissection infratemporal region of ten human cadavers and show that the muscle sphenomandibular corresponds to the deep portion of the temporalis muscle since there is not a septum muscular separating these muscular structures by other authors (Ramalho et al.; Dunn et al.). The MRI images also showed that this muscle is important to masticatory movements but is not involved in the origin of headaches in patients as described previously by Dunn et al.

Shimokawa et al., after observing 10 temporal muscles, could identify the organization of the bundles and their respective innervation. The presence of a main muscular part was clearly observed, with fibers arranged in fan shape, as well as three other bundles denominated as anterior-medial, anterior-lateral and semi-lateral. The authors concluded, according to the observation of the origin, insertion and muscular innervations, that those bundles are an integral part of the temporalis muscle and not an independent muscle, although the anterior-medial and anterior-lateral bundles have been recently described as a new muscle (Dunn et al.).

Gaudy et al. verified in a layer-by-layer dissection and by anatomical cuts on different spatial planes that the temporalis muscle has a different architecture from the other mandibular elevator muscles. Indeed this muscle does not have the pennate structure of the masseter and pterygoid muscles. This study showed three distinct anatomical portions in the middle of the temporalis muscle, which corresponds to its functional classification.

Therefore, based on the somewhat scarce data found in the literature pertinent to the deep bundle of the temporal muscle, seeing that most of the treatises of classical anatomy just make mention of the muscle as a whole possessing a superficial bunch and composed of three differentiated types of muscular fibers (Chiarugi, 1924; Gardner \& O'Rahilly, 1978), attention was drawn to the total absence of individual fascia separately wrapping each one of the three temporalis muscle bundles, as well as to the existent relationship of that bundle with the maxillary artery. This discovery serves to corroborate the concept that, these bundles form a single entity, supporting the cited authors' classic description.

\section{CONCLUSIONS}

Using as a basis, the observations of the dissected material in this paper, it can be concluded that: 1) The temporalis muscle is a single entity, presenting three bundles highlighted in $100 \%$ of the pieces dissected by the frontal route: deep or medial, intermediary, and superficial or lateral. Such an assertion is based on the total absence of muscular fascia between the bundles. 2) The aforementioned sphenomandibular muscle by Dunn et al. is, in fact, the deep or medial bundle of the temporalis muscle, and 3) The presence of the bundle, denominated for this paper as intermediary, stimulates new verifications as to the functions of the temporalis muscle.

PALOMARI, E. T.; PICOSSE, L. R.; TOBO, M. P.; ISAYAMA, N. R. \& DA CUNHA, M. R. ¿Músculo esfenomandibular o fascículo profundo del músculo temporal? Int. J. Morphol., 31(4):1158-1161, 2013.

RESUMEN: El músculo denominado como esfenomandibular por un grupo de autores o de acuerdo con estudios recientes, de fascículo profundo del músculo temporal, presenta importantes relaciones anatómicas, especialmente en un contexto médicoodontológico. En vista de esta discusión, el objetivo fue observar la morfología mediante la disección de cabezas conservadas en formaldehído, utilizando dos técnicas diferentes para acceder a la región del músculo, designadas como vías de acceso trans-cigomáticas y frontales. Los resultados mostraron, por la observación de las disecciones frontales, la presencia de fascículos que se ubican independientemente al vientre muscular del fascículo profundo, denominado fascículo intermediario. Este fascículo presentó dos porciones, una superior carnosa y una inferior tendinosa, que continuó con la parte tendinosa del fascículo superficial presente en la superficie interna del proceso coronoides. En vista de las observaciones realizadas, se puede concluir que debido a la ausencia total de la fascia muscular entre sus paquetes, el músculo temporal es una entidad única que presenta tres fascículos, el profundo, intermedio y superficial.

PALABRAS CLAVE: Músculo esfenomandibular; Disección; Fascículo profundo del músculo temporal. 


\section{REFERENCES}

Chiarugi, G. Systematic anatomy: Apparecchio MuscolareApparecchio Vascolare. Anatomy dell'uomo. $2^{\mathrm{a}}$ ed. Milano, Società Editrice Libraria, 1924.

Dunn, G. F.; Hack, G. D.; Robinson, W. L. \& Koritzer, R. T. Anatomical observation of a craniomandibular muscle originating from the skull base: the sphenomandibularis. Cranio, 14(2):97-103; discussion 104-5, 1996.

Ernest, E. A. 3rd.; Martinez, M. E.; Rydzewski, D. B. \& Salter, E. G. Photomicrographic evidence of insertion tendonosis: The etiologic factor in pain goes temporary tendonitis. J. Prosthet. Dent., 65(1):127-31, 1991.

Gardner, E.; Gray, J. D. \& O'Rahilly, R. Anatomy-I Study regional of the Human Body. $4^{\text {th }}$ ed. Rio de Janeiro, Guanabara Koogan, 1978.

Gaudy, J. F.; Zouaoui, A.; Bravetti, P.; Charrier, J. L. \& Laison, F. Functional anatomy of the human temporal muscle. Surg. Radiol. Anat., 23(6):389-98, 2001.

Geers, C.; Nyssen-Behets, C.; Cosnard, G. \& Lengelé, B. The deep belly of the temporalis muscle: an anatomical, histological and MRI study. Surg. Radiol. Anat., 27(3):184-91, 2005.

Miller, J. A. Craniomandibular Muscles: Their Roles in Function and Form. Boca Raton, CRC Press, 1991.

Poirier, A. Les muscles de la tõte et du cou. In: Poirier A. \& Charpa, A. (Eds.). Traité d'anatomie humaine. Paris, Masson, 1912.

Ramalho, L. R. T.; Landucci, C. \& Porciúncula, H. F. Estudo macro e mesoscopico do feixe profundo do músculo temporal humano. Rev. Fac. Odontol. Araquarara, 1:105-10, 1978.

Sedlmayr, J. C.; Kirsch, C. F. \& Wisco, J. J. The human temporalis muscle: superficial, deep, and zygomatic parts comprise one structural unit. Clin. Anat., 22(6):655-64, 2009.

Shankland, W. E. 2nd.; Negulesco, J. A. \& O'Brian, B. The “preanterior belly" of the temporalis muscle: a preliminary study of a newly described muscle. Cranio, 14(2):106-113, 1996.

Shimokawa, T.; Akita, K.; Soma, K. \& Sato, T. Innervation analysis of the small muscle bundles attached to the temporalis: Truly new muscles or merely derivates of the temporalis? Surg. Radiol. Anat., 20(5):329-34, 1998.

Shon Ybarra, M. A. \& Bauer, B. Medial portion of muscle temporalis and its potential involvement in facial pain. Clin. Anat., 14(1):25-30, 2001.

Sicher, H. \& Tandler, J. Anatomy for Dentists. São Paulo, Atheneu, 1981.
Türp, J. C.; Cowley, T. \& Stohler, C. S. Media hype: musculus sphenomandibularis. Acta Anat. (Basel), 158(2):150-4, 1997.

Correspondence to:

Prof. Dr. Marcelo Rodrigues da Cunha

Department of Morphology and Pathology

Faculty of Medicine of Jundiaí

Rua Francisco Telles, 250, Vila Arens

CEP. 13202-550, Cx. Postal 1295

Jundiaí São Paulo

BRAZIL

Email: cunhamr@hotmail.com

Received: 27-03-2013

Accepted: 10-08-2013 